\title{
Endocrine Disruption Potentials of Bisphenol A Alternatives - Are Bisphenol A Alternatives Safe from Endocrine Disruption?
}

\author{
Kyunghee Ji* and Kyungho Choi \\ School of Public Health, Seoul National University, Korea
}

\begin{abstract}
Objectives: Although a great body of knowledge is available on the toxicity of bisphenol A (BPA), little is known about that of BPA alternatives, such as bisphenol analogues (BPs) or $\operatorname{Tritan}^{\mathrm{TM}}$ copolyesters. This review provides a summary of the available information on the toxicity of BPs and three components of $\operatorname{Tritan}^{\mathrm{TM}}$, with a special focus on endocrine disruption.

Methods: We collected from the literature a battery of in vitro and in vivo assay data developed to assess endocrine disruption of four BPs (bisphenol AF, B, F, and S) and three major components of $\operatorname{Tritan}^{\mathrm{TM}}$ ((di-methylterephthalate (DMT), 1,4-cyclohexanedimethanol (CHDM), and 2,2,4,4-tetramethyl-1,3-cyclobutanediol (TMCD)).

Results: Several alternative compounds were identified as possessing comparable or even greater endocrinedisrupting effects than BPA in in vitro and in vivo studies.

Conclusions: Potential endocrine disruption of BPA alternatives requires further studies on health consequences in experimental animals and in humans following longer term exposure.
\end{abstract}

Keywords: bisphenols, endocrine disruption, Tritan

\section{Introduction}

Endocrine disruptions due to exposure to chemicals in various consumer products, e.g., plastics have received great attention. ${ }^{1)}$ Among them, bisphenol A (BPA; 2,2-bis(4-hydroxydiphenyl)propane, which has been produced over eight billion pounds each year worldwide, is frequently used as a monomer in the manufacture of polycarbonates and epoxy resins. ${ }^{2}$ As BPA can disrupt steroidogenesis and act as a weak estrogen receptor agonist, concerns on adverse health outcomes, especially on reproduction and development, are increasing., ${ }^{3,4)}$ A large number of biomonitoring studies indicate widespread exposure to BPA in adults, adolescents, and children from several different countries, ${ }^{5}$ ) while the results from toxicokinetic studies that determined the disposition of BPA in humans after oral administration of BPA are at odds with them. ${ }^{6,7)}$ In 2011, the European
Commission has applied the precautionary principle on BPA and restricted its use in plastic infant feeding bottles. ${ }^{8)}$ In response to this restriction, a number of alternative compounds, such as bisphenol AF (BPAF; 2,2-bis(4-hydroxyphenyl)hexafluoropropane), bisphenol B (BPB; 2,2-bis(4-hydroxyphenyl)butane), bisphenol F (BPF; bis(4-hydroxydiphenyl)methane), and bisphenol S (BPS; bis(4-hydroxyphenyl)sulfone), began to be often used increasingly as component of plastic substitutes. ${ }^{2)}$ In addition, a novel plastic is also manufactured by Eastman Chemical Company (Kingsport, TN, USA) utilizing three monomers, dimethylterephthalate (DMT), 1,4-cyclohexanedimethanol (CHDM), and 2,2,4,4-tetramethyl-1,3-cyclobutanediol (TMCD) in various ratios, marketed under a trade name of $\operatorname{Tritan}^{\mathrm{TM}}$.9)

The production and consumption of bisphenol analogues (BPs; Table 1) that are structurally similar to BPA with two hydroxyphenyl functionalities have

Corresponding author: School of Public Health, Seoul National University, Gwanak, Seoul, 151-742, Republic of Korea, Tel: 82-2-880-2795, Fax: 82-2-745-9104 E-mail: jkh526@snu.ac.kr

Received: 7 February 2013, Revised: 13 February 2013, Accepted: 22 February 2013 
Table 1. Chemical structures of bisphenol A and its alternatives which are commonly used in consumer products

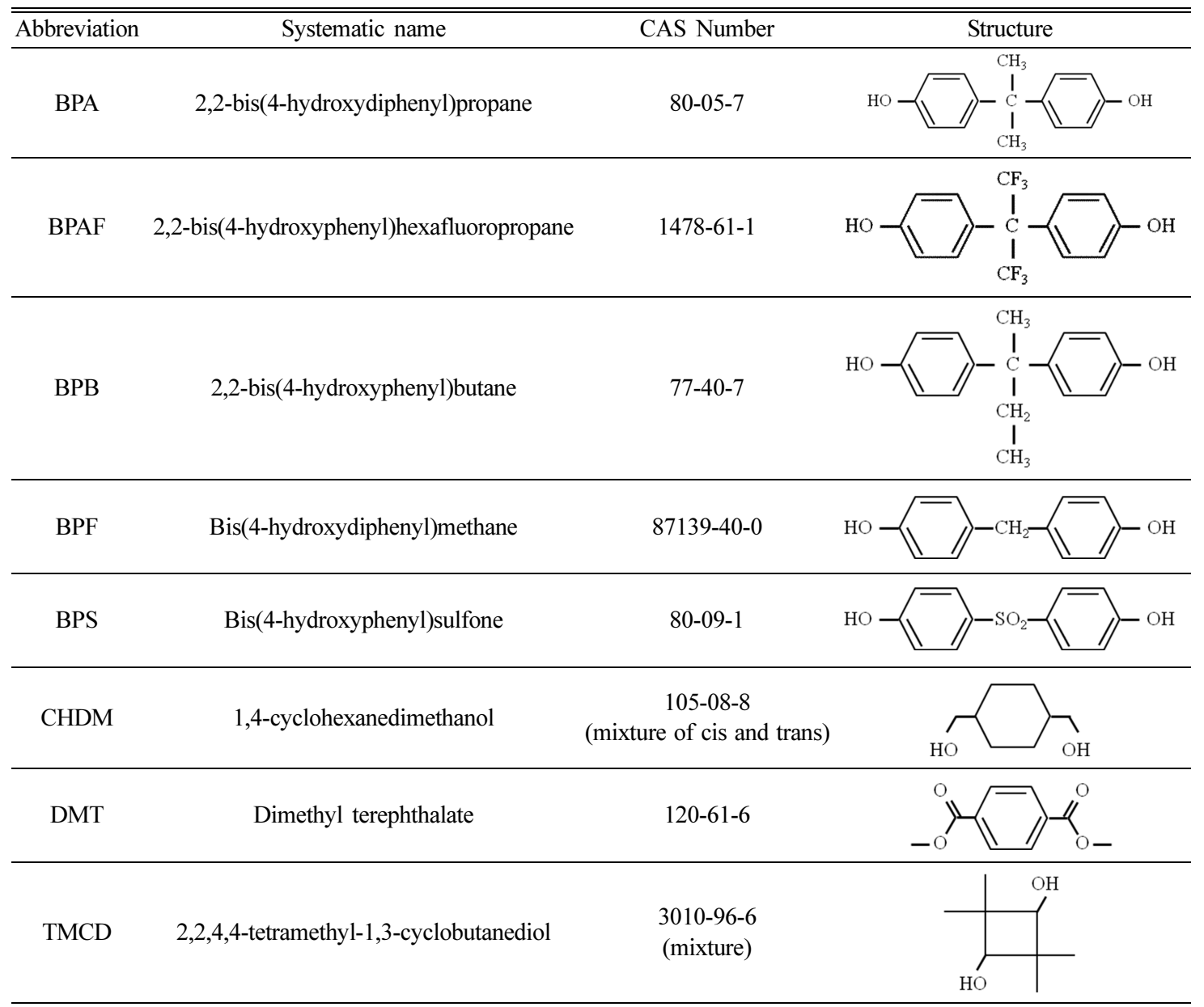

increased recently. ${ }^{10)}$ BPAF, a fluorinated derivative of BPA, is widely used in polycarbonate copolymers in high-temperature composites, electronic materials, gas-permeable membranes, and specialty polymer applications. ${ }^{11-14)}$ Approximately 10,000-500,000 pounds of BPAF are produced annually in the United States. ${ }^{15)}$ BPB, a BPA analogue having a butyl chain instead of a propyl chain between the two phenol moieties, is utilized in the manufacture of resins and plastics. ${ }^{16)}$ BPF, which differs from BPA only by the lack of two methyl groups on the central carbons, has a broad range of industrial applications such as lacquers, varnishes, liners, adhesives plastics, food packaging, dental sealants, and water pipes. ${ }^{17)}$ BPS, whose two phenolic rings are joined together with sulfur, has excellent stability against high temperature and resistance to sunlight. ${ }^{18)}$ BPS has been introduced to the market as a component of plastic substitutes for the production of babybottles ${ }^{19)}$ or used as a developer in dyes for thermal paper. ${ }^{20)}$

Tritan copolyester is used in packaging of beverages, edible oil, and foods, as well as for food contact films and foils including microwave packaging. ${ }^{21)}$ Three important co-monomers of Tritan, namely CHDM, DMT, and TMCD, were used for production of polyethylene terephthalate (PET) bottle in Lock \& Lock $^{\circledR}$ company. DMT is nominated as a high production volume chemical, both in the United States ${ }^{22}$ and Organization for Economic Co-operation and Development. ${ }^{23)}$

Recent studies have reported the occurrence of BPA alternatives in environmental samples, consumer products, food, and human specimens (Table 2). BPAF has been found in $76 \%$ of the 41 


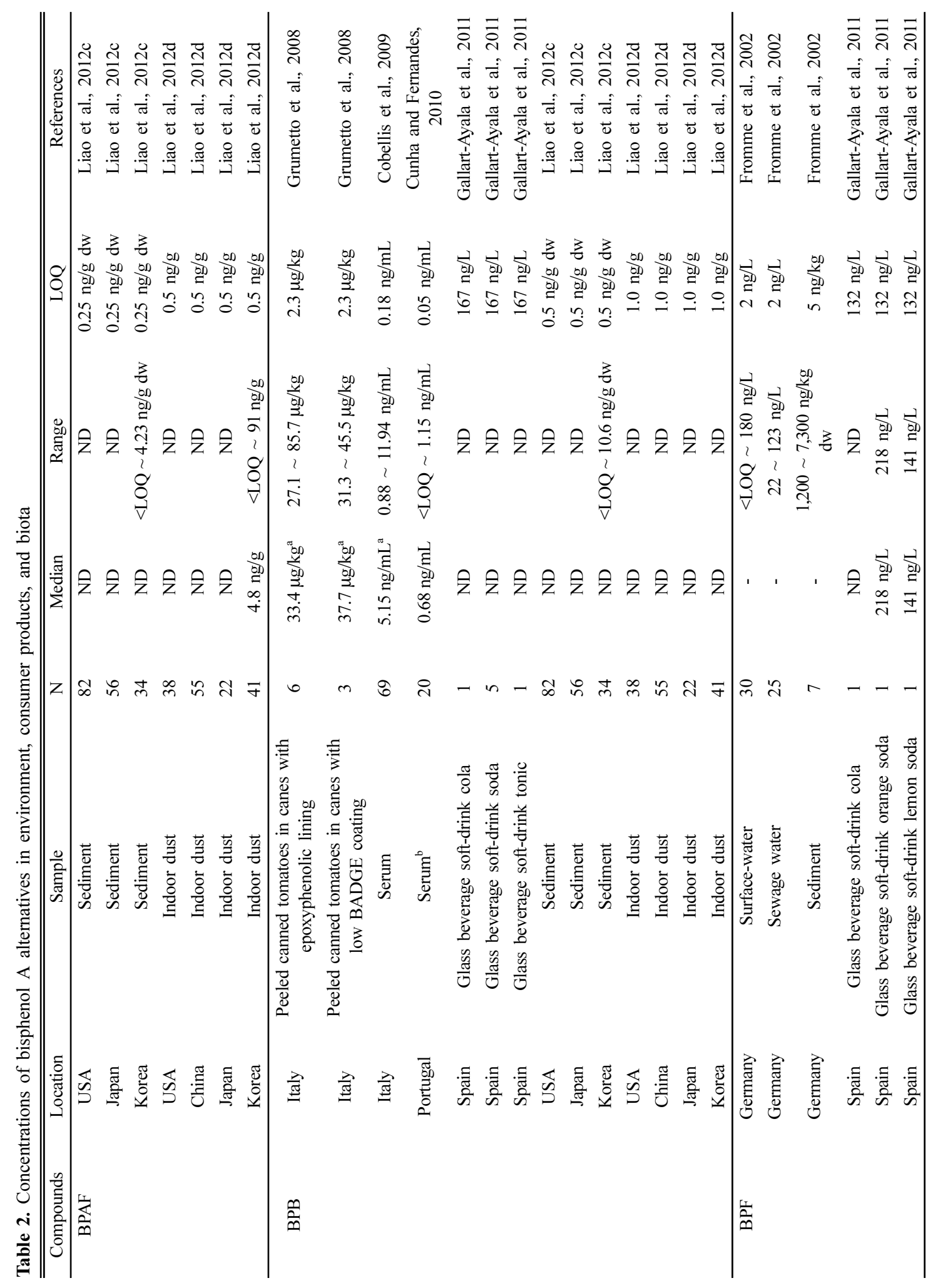




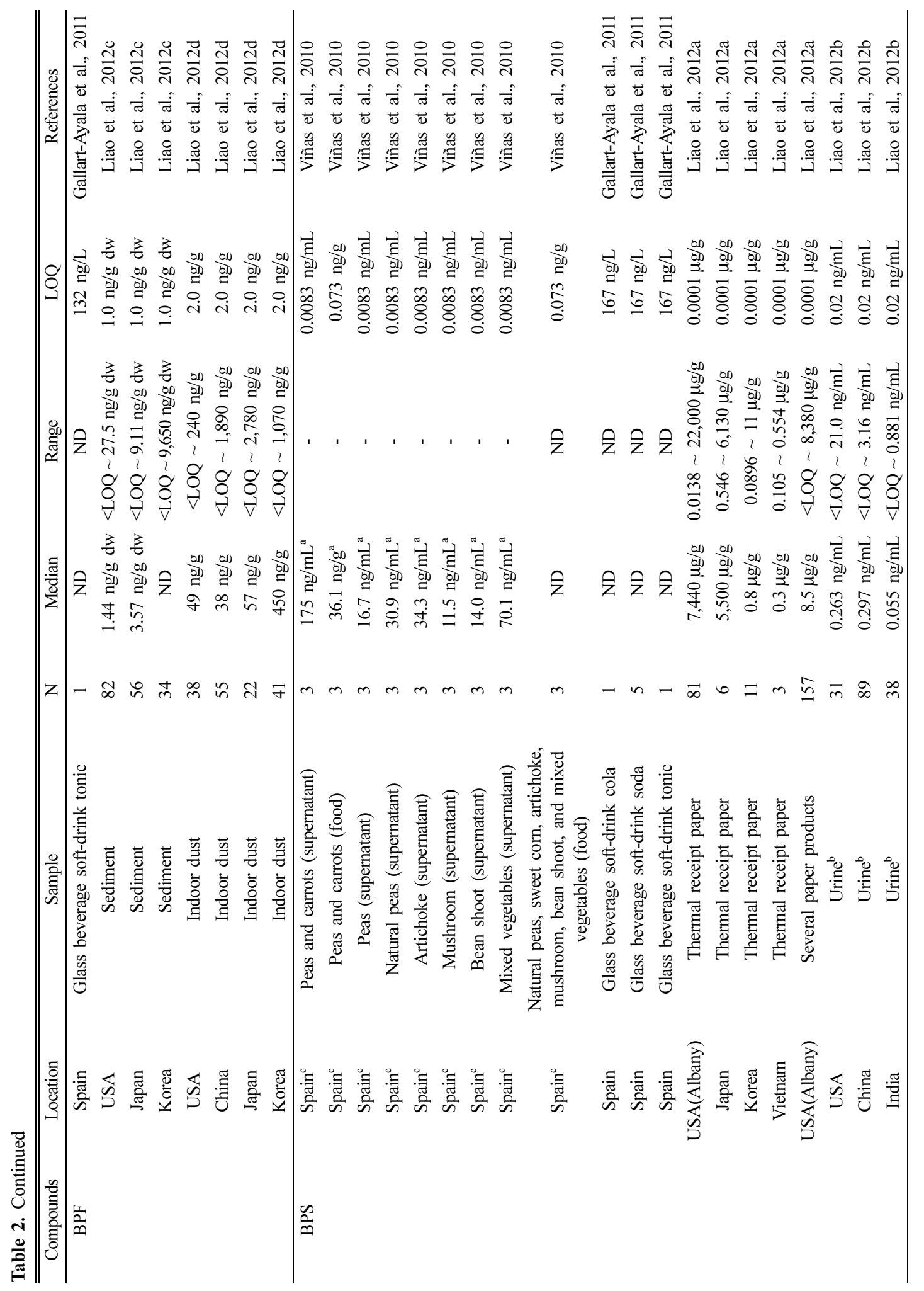




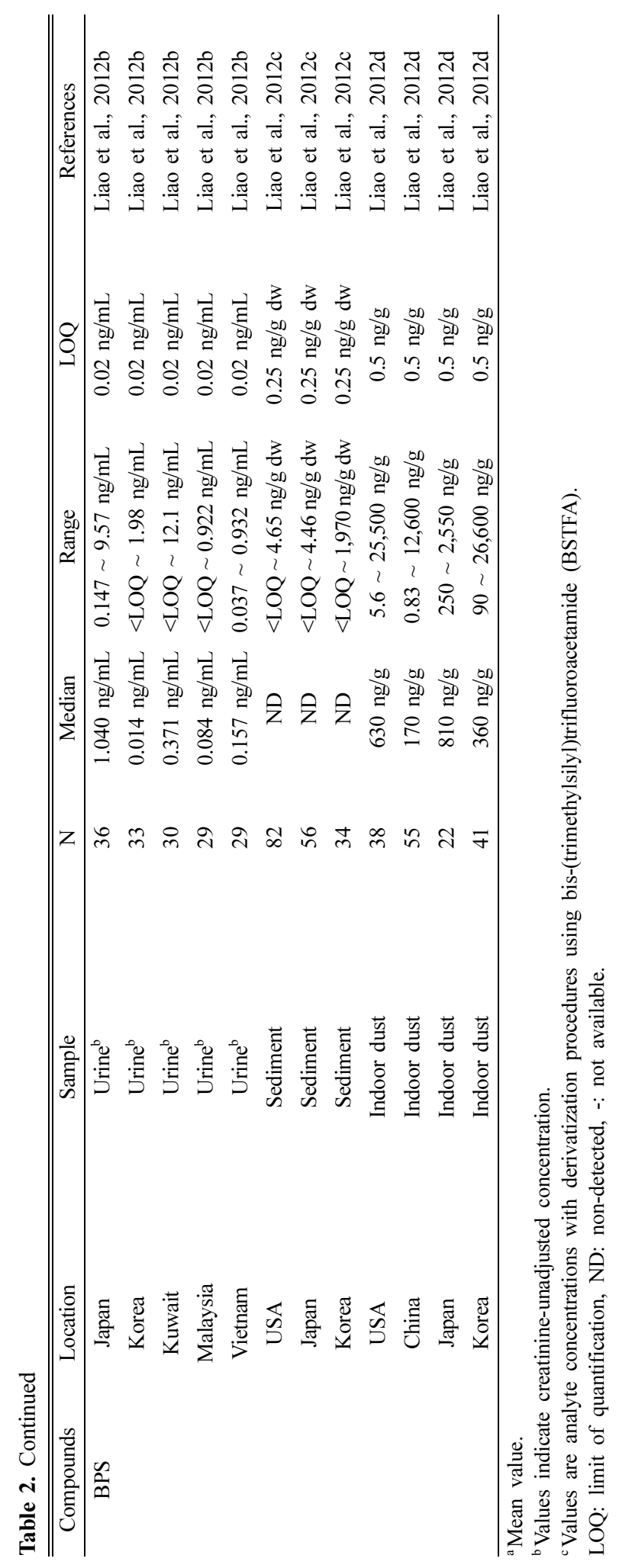


indoor dust samples collected in South Korea (median $4.8 \mathrm{ng} / \mathrm{g}$ ). ${ }^{24)} \mathrm{BPB}$ has been found in human serum from Italy (mean $5.15 \mathrm{ng} / \mathrm{mL}$ ) ${ }^{25)}$ and Portugal (mean $0.68 \mathrm{ng} / \mathrm{mL}$ ), ${ }^{26}$ and in canned foods (mean $42.3 \mathrm{ng} / \mathrm{g}) .{ }^{27)} \mathrm{BPF}$ has been reported in surface water, sewage, and sediments at concentrations ranging from below the limit of quantification (LOQ) to $0.180 \mu \mathrm{g} / \mathrm{L}, 0.022$ to $0.123 \mu \mathrm{g} / \mathrm{L}$, and 1.2 to $7.3 \mu \mathrm{g} / \mathrm{kg}$, respectively. ${ }^{17)} \mathrm{BPF}$ was reported to occur in soft drinks at concentrations ranging from below LOQ to $0.22 \mu \mathrm{g} / \mathrm{L}^{28)}$ The highest median concentration of BPF $(450 \mathrm{ng} / \mathrm{g})$ was found in dust from South Korea, which was ten folds higher than that detected in samples of USA, China, and Japan. ${ }^{24)}$ BPS has been found in thermal receipt papers at concentrations comparable to those of BPA (several tens of milligrams per gram $)^{29,30)}$ and in sediment samples collected from various countries. $^{31)}$ Widespread exposure of the general population in various countries to BPS has been demonstrated through biomonitoring studies. ${ }^{2)}$ BPS has been found in canned foodstuffs at concentrations on the order of several tens of nanograms per gram. ${ }^{27,32)}$

Since the discharges into the environment of BPs and Tritan are estimated to increase rapidly, ${ }^{9,33)}$ environmental and health risk potentials of BPA alternatives are of growing concern. Unlike BPA of which endocrine toxicity and various health consequences have received thorough investigations, very limited attention has been paid to the toxicity of BPA alternatives until now. This review focuses on endocrine disruption and presents what we know about the endocrine disruption potentials of BPs and the three monomers of Tritan to understand the current status of knowledge and to identify areas of future research.

\section{Methods}

In this review, we provides a summary of the available information on the estrogenicity and androgenicity of four BPs (BPAF, BPB, BPF, and BPS) and three monomers of Tritan copolyesters (CHDM, TMCD, and DMT) which have been frequently used as BPA alternatives. Only toxicity data that measured estrogenicity/anti-estrogenicity and androgenicity/anti-androgenicity in in vitro cellbased and in in vivo assay in rat were summarized.
Specifically, the following studies were summarized:

- In vitro estrogen receptor binding assays (alpha and beta isoforms)

- In vitro androgen receptor binding assays

- In vitro estrogen and androgen receptor transactivation assays (mammalian cells and yeast)

- In vivo estrogenicity assays (uterotrophic assay and steroidogenic assay)

- In vivo androgenicity assays (Hershberger assay)

\section{Results and Discussion}

A. Estrogenic activities of BPs

Several studies have been published confirming the estrogenic and anti-androgenic activity of BPA alternatives in diverse in vitro and in vivo assay which are summarized in Tables 3-4. Analysis of the structure-activity relationship of BPA and its related compounds implied that key structural requirement for estrogenic and anti-androgenic activity of BPs is the phenolic hydroxyl group (Fig. 1). ${ }^{34)}$ In addition, 4-hydroxyl group on the A-phenyl ring and a hydrophobic group of the propane moiety are suggested to regulate estrogenic and anti-androgenic activities (Fig. 1). ${ }^{34)}$ For example, the increase of E2 activity by BPAF and BPB could be explained by hydrophobic substituents in place of the 1-methyl group of the propane moiety. Unhindered hydroxyl group on an aryl ring and a hydrophobic group attached para to the hydroxyl group are also important factors for estrogen receptor (ER) ligand activity. ${ }^{35)}$ It was predicted that BPF and BPS, which have a para hydroxyl group on each of the phenol rings, may have modulating effects toward ER binding potency. ${ }^{18,36)}$

\section{Estrogenic activities of BPAF}

BPAF may possess greater toxicological implication than BPA because trifluoromethyl (CF3) group which is substituted for methyl $(\mathrm{CH} 3)$ group of BPA is much more electronegative and therefore potentially more reactive. This type of substitution has been reported to increase estrogenic activity in vivo and in vitro. ${ }^{12,13,34,37)}$ An ER-luciferase reporter assay using MCF-7 cell line demonstrated that the estrogen activity of BPAF was about one order of magnitude greater than that of $\mathrm{BPA}{ }^{34)}$ Daily subcutaneous injections of $100 \mathrm{mg} / \mathrm{kg}$ BPAF to 


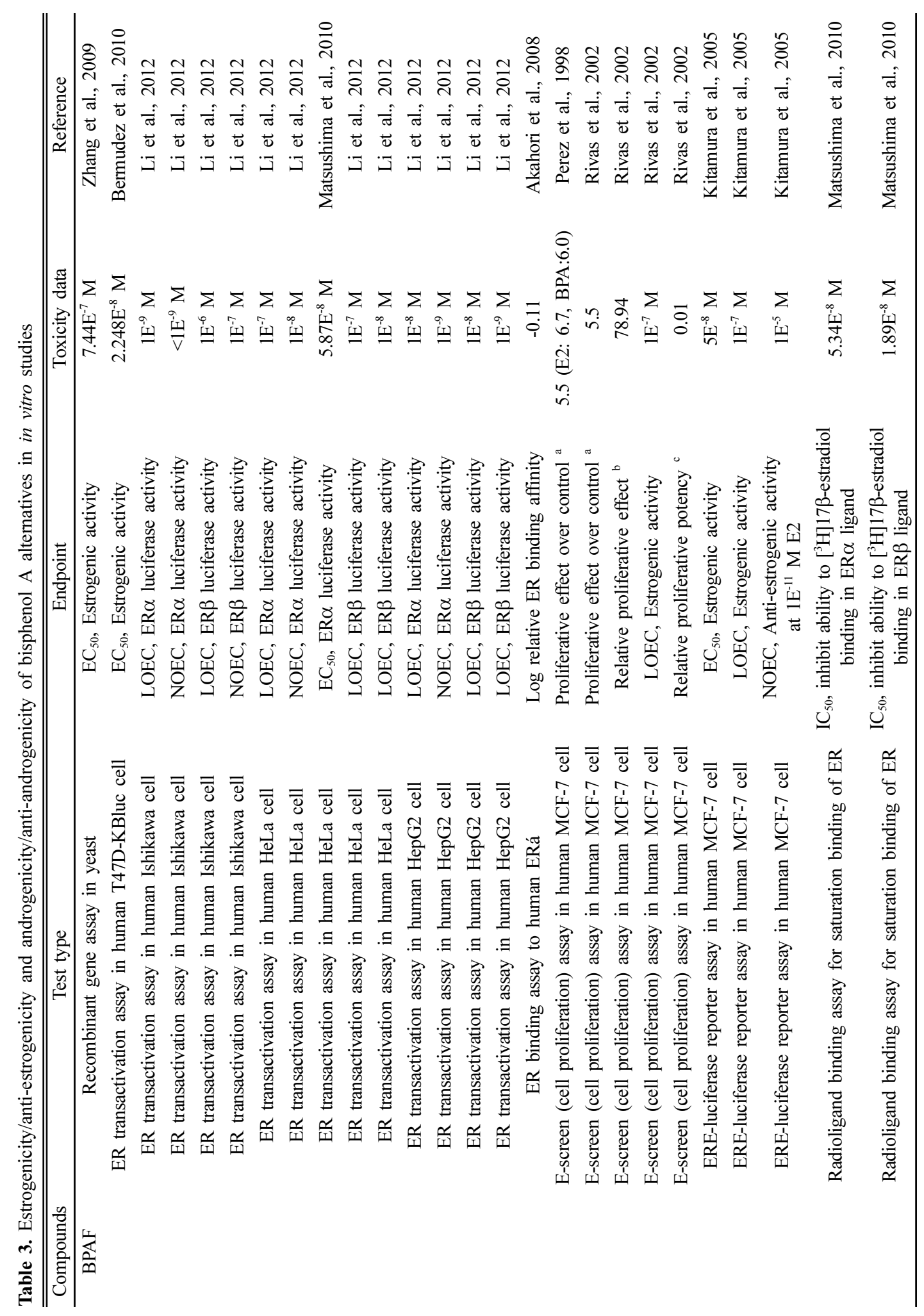




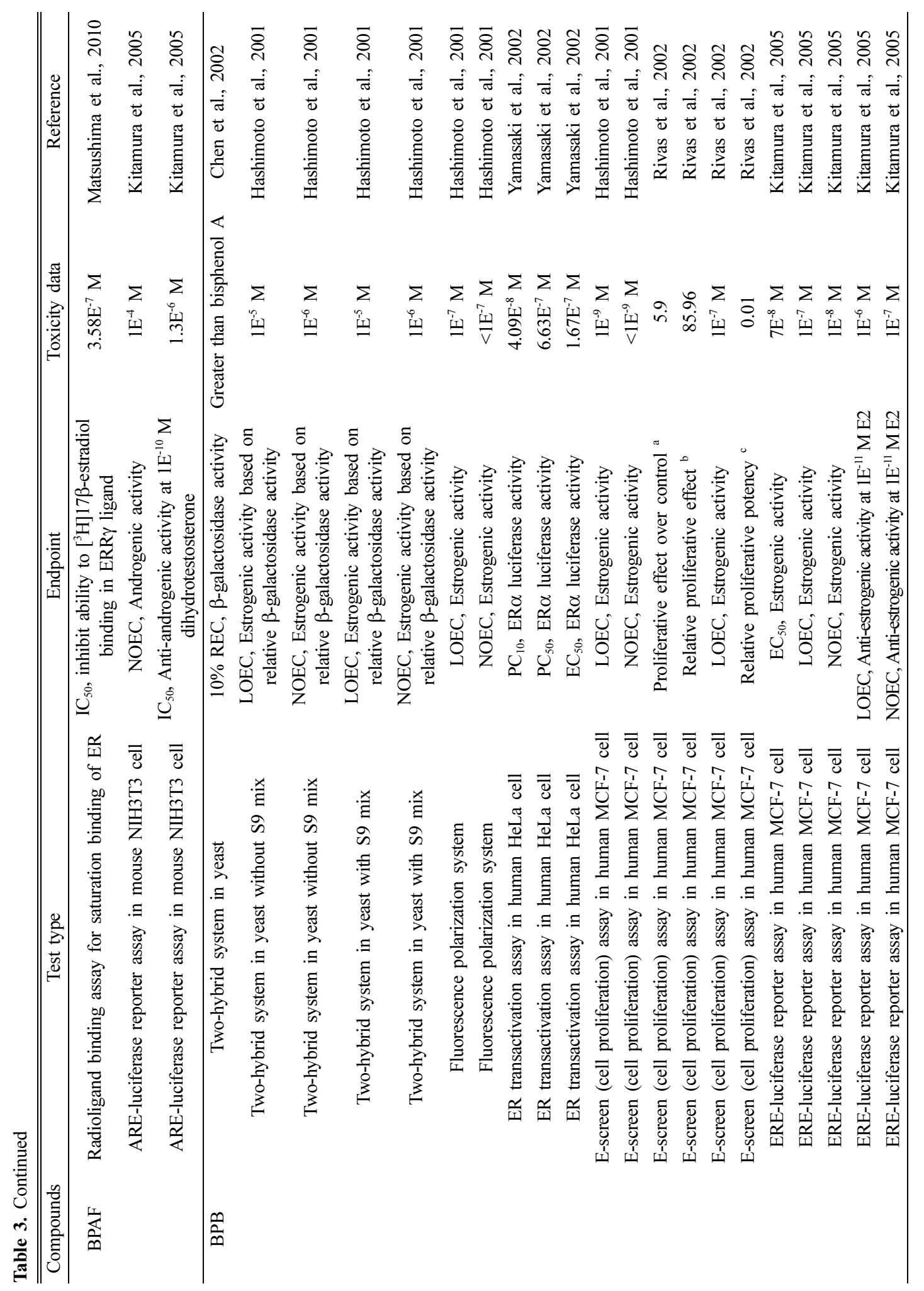




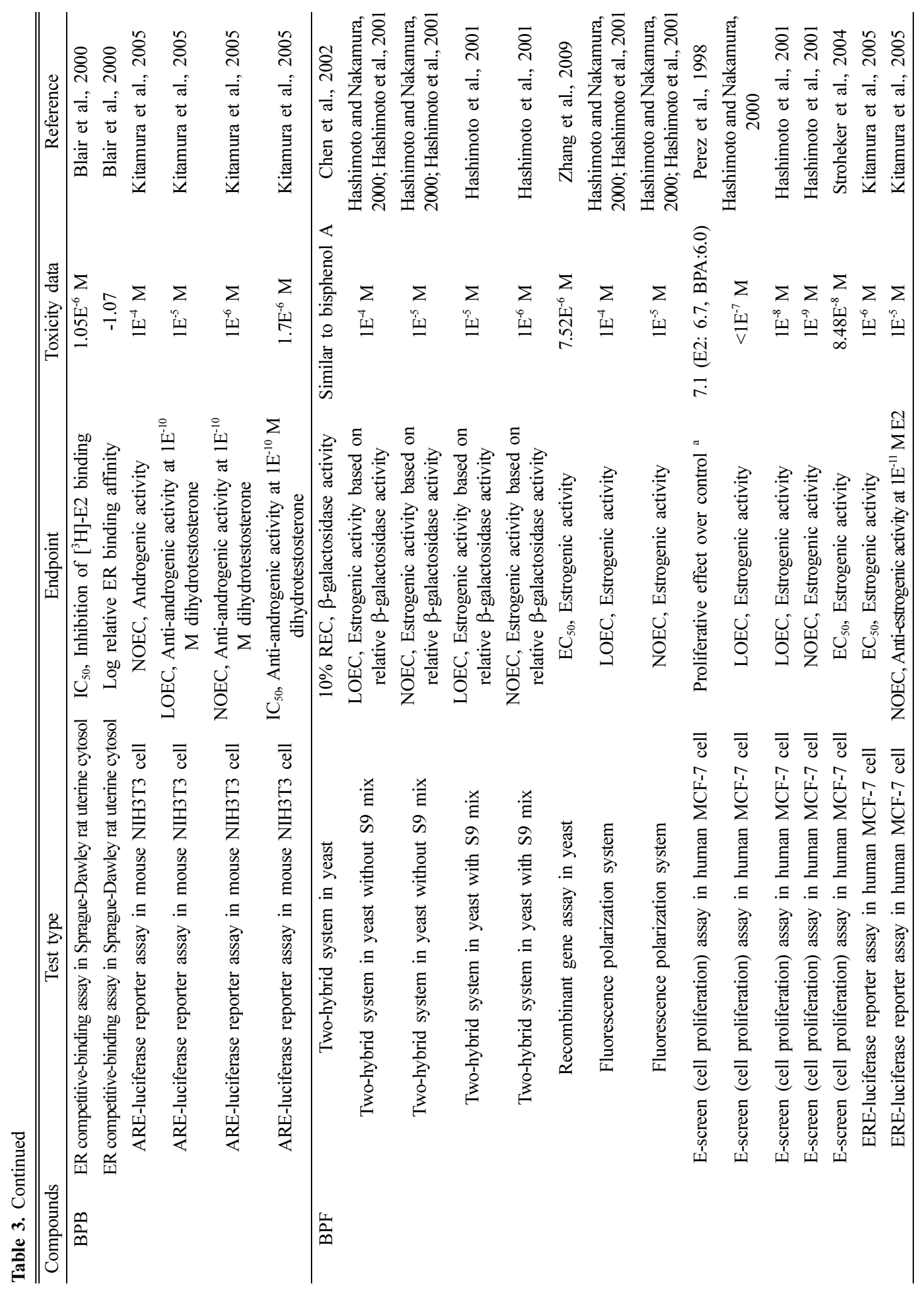




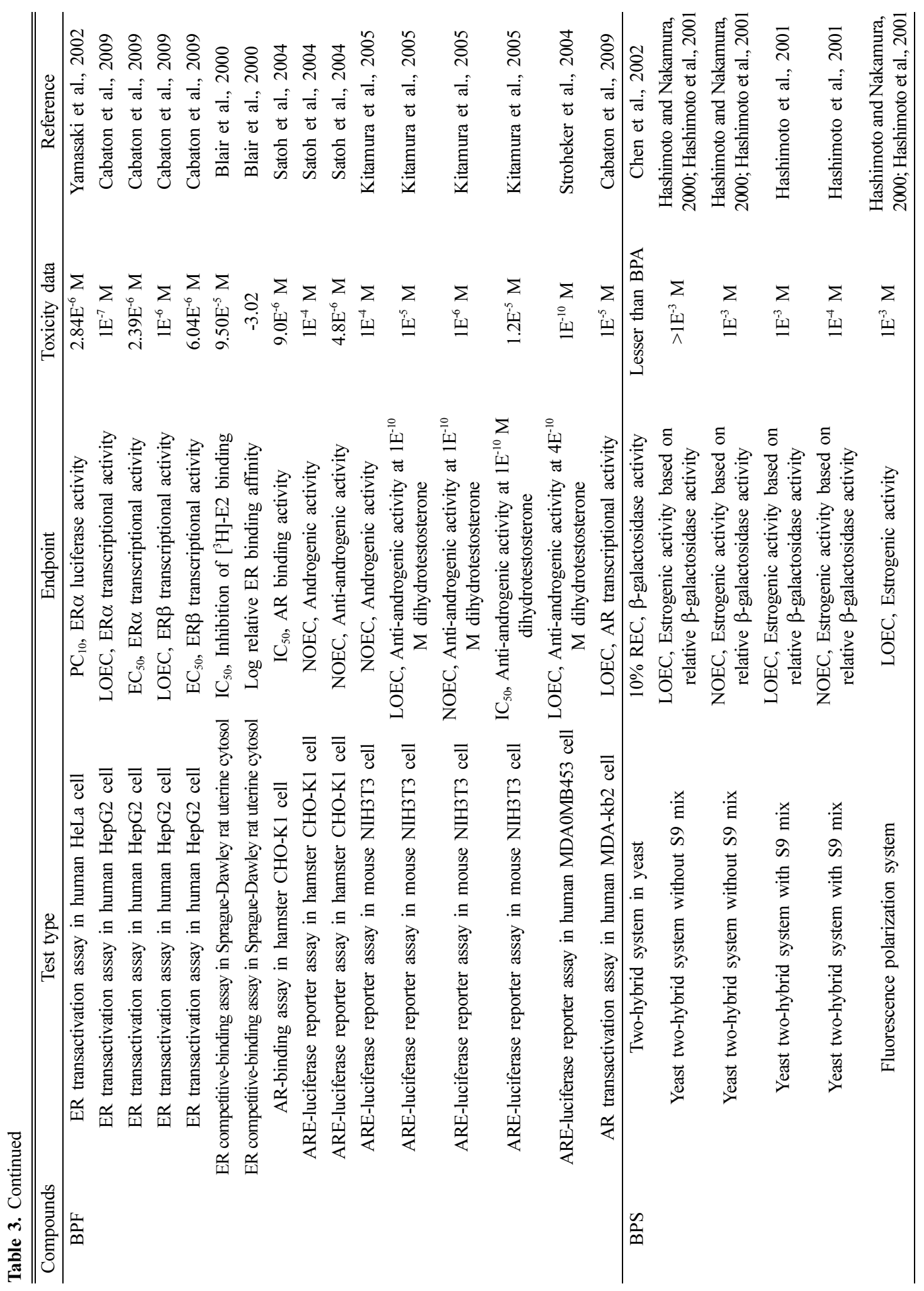




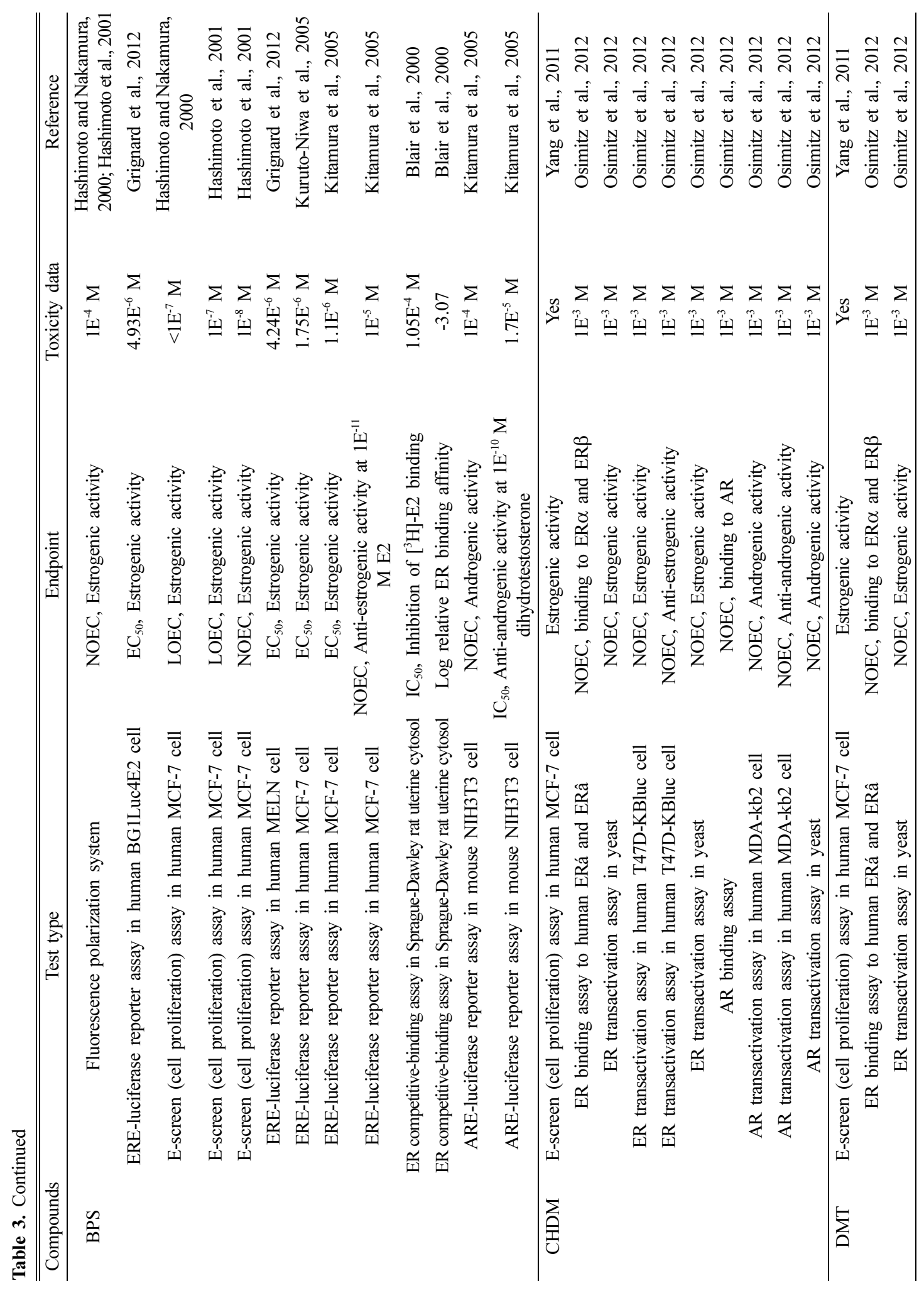




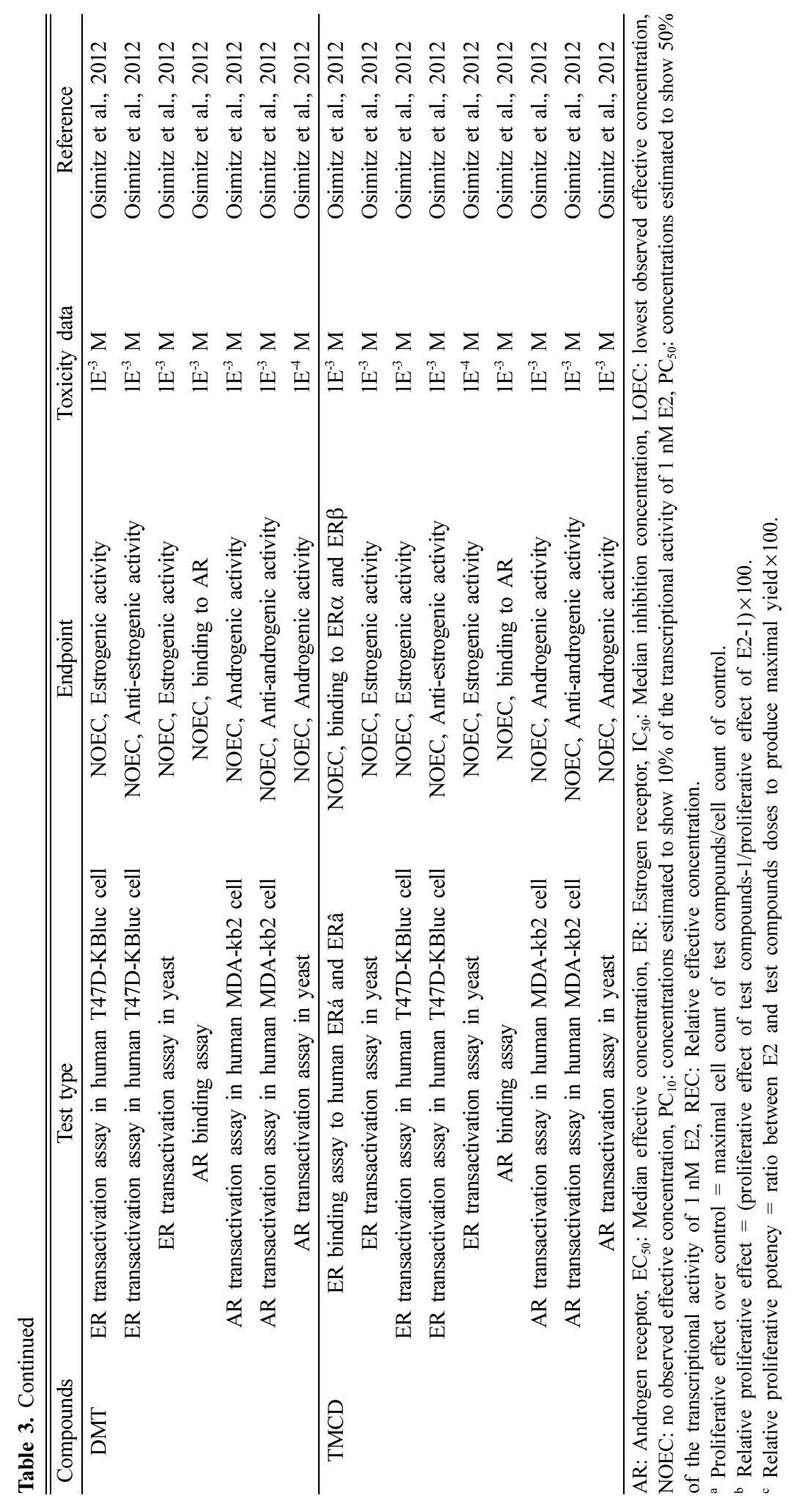




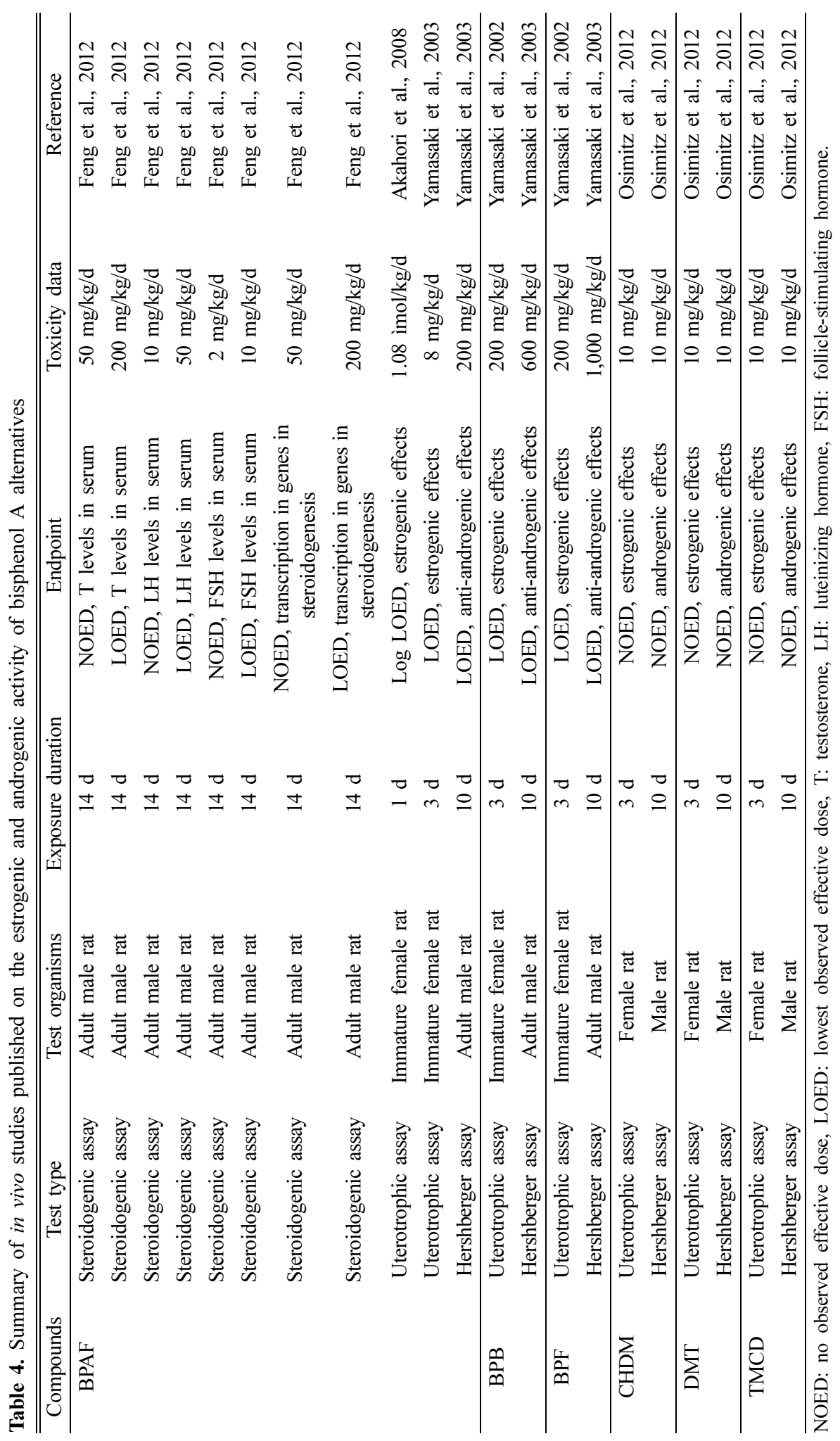




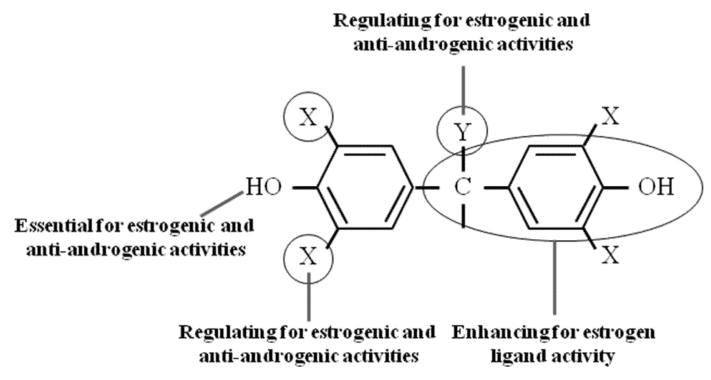

Fig. 1. Structural characteristics of bisphenol-related compounds which might possess endocrinedisrupting activity (modified from Kitamura et al. $\left.(2005)^{34}\right)$

immature female rats for three days led to a $337 \%$ increase in uterus size, compared to only a $197 \%$ increase when exposed to $200 \mathrm{mg} / \mathrm{kg}$ BPA. ${ }^{15}$

BPAF has been shown to induce estrogendependent responses via binding to $\mathrm{ER} \alpha$ and ER $\beta .^{11,12,13,37)}$ The binding affinity of BPAF was approximately 20 times stronger and 48 times stronger than that of BPA as a ligand for ER $\alpha$ and ER $\beta$, respectively. ${ }^{13)}$ High binding activity of BPAF for $\operatorname{ER} \beta$ suggests that the binding pocket of $\operatorname{ER} \beta$ possesses specific structural elements that interact much more favorably with the CF3 groups of BPAF than with the $\mathrm{CH} 3$ groups of BPA. In Ishikawa and HepG2 cells, the agonistic effects of BPAF for ER $\alpha$ were stronger than that of BPA $(10 \mathrm{nM}$ BPAF vs. $100 \mathrm{nM}$ BPA). ${ }^{12)}$ However binding to estrogen-related receptor gamma (ERR $\gamma)$ was weaker than BPA, suggesting less favorable interaction of ERR $\gamma$-ligand binding domain (LBD) with the CF3 groups. ${ }^{13)}$

In uterotrophic assay employing immature rat, uterine weight increased significantly in rats given 8, 40, and $100 \mathrm{mg} / \mathrm{kg}$ BPAF, suggesting estrogen agonist. $^{38)}$ The results of Hershberger assay showed that BPAF decreased body weight-gain and spontaneous locomotion in the rats treated with 200 and $600 \mathrm{mg} / \mathrm{kg}$ BPAF, suggesting anti-androgen activity. $^{38)}$

BPAF may impair pituitary-gonadal function at different levels by increasing $\mathrm{LH}$ and $\mathrm{FSH}$ concentrations and decreasing testosterone levels in serum. ${ }^{39)}$ It appears that the inhibition of androgen biosynthesis was not a result of altered regulatory function of the LH-dependent signaling pathway but was more likely a direct result of BPAF's ability to reduce the expression of steroidogenic genes such as SR-B1, StAR, P450scc, and 17ßHSD. Sharp decrease in testosterone concentration and reduction in gene transcriptions and protein levels involved in steroidogenesis suggested that the testes may be a primary target organ of BPAF exposure.

\section{Estrogenic activities of BPB}

Estrogenicity of BPB is suspected in part because of the substitution of the propane bridge of BPA to butane, which is related to its estrogenic activity. It was reported that higher estrogenic responses were obtained from longer alkyl substituent at the bridging carbon in MCF-7 cells. ${ }^{14)}$ Recently Chen et al. ranked diphenylalkanes without any modifications by their estrogenic potency, and reported the order of BPB (C4) > BPA (C3) bisphenol E (1,1-bis(4hydroxyphenyl)ethane; BPE) (C2) BPF (C1). ${ }^{33)}$

$\mathrm{BPB}$ has been shown to possess estrogenic properties in various in vitro and in vivo experiments. BPB showed considerably higher estrogenic activity than BPA in the yeast two-hybrid assay. ${ }^{33)}$ This compound also exhibited significant increase of MCF-7 cell growth in the E-screen tes $^{40,41)}$ as well as greater luciferase activity in MCF7 cells. ${ }^{34)}$ Moderate binding affinity to ER was also reported in Sprague-Dawley rat uterine cytosol. ${ }^{35}$ ) Yamasaki et al. found that BPB has estrogenic activity both in ER transactivation assay in HeLa cell and uterotrophic assay in female rat, however, the estrogenic potencies obtained in in vitro assay do not completely correspond to the uterotrophic potency in in vivo test. ${ }^{42)}$

\section{Estrogenic activities of BPF}

BPF has been shown to induce estrogenic activity in vivo and in vitro. In in vivo, BPF exhibited estrogen agonistic properties in the uterotrophic assay. ${ }^{42)}$ In in vitro assay using a yeast two-hybrid system BPF was identified as the most estrogenic compound among the tested chemicals that were present in food packaging material or used in dentistry. ${ }^{40,43)}$ BPF has also exhibited estrogenic activity in yeast recombinant gene assay. ${ }^{44)}$ In human cells, the proliferative response of MCF-7 cells (EScreen assay) increased in a concentration dependent manner. ${ }^{14,40,43,45)}$ The latter authors showed that, according to the respective median effective concentration $\left(\mathrm{EC}_{50}\right)$ values for proliferation of MCF-7 cell, BPF was more pronounced than BPA. 
Moderate binding affinities of BPF to ER in MCF7 cell, $^{34)}$ HeLa cell, ${ }^{42)}$ HepG2 cell, ${ }^{46)}$ and SpragueDawley rat uterine cytosol ${ }^{35)}$ were reported.

Some of effects of BPF exposure are mediated by binding to nuclear steroid receptors (ER $\alpha$ and $E R \beta)$ and inducing estrogenic signals, which may subsequently modify estrogen-responsive gene expression in HepG2 cells. ${ }^{46}$ These data are in agreement with Kitamura et al. who used an EREluciferase reporter assay in MCF-7 cells. ${ }^{34)}$

Anti-androgenic activities of BPF were reported in in vitro and in vivo systems. BPF can compete with 5- $\alpha$ dihydro-testosteron (5- $\alpha$ DHT) for binding with $\mathrm{AR}$ and exhibits a significant anti-androgenic activity in MDA-kb2 cells. ${ }^{46)}$ These results are in agreement with Satoh et al. (2004) who observed a decrease of 5- $\alpha$ DHT-induced luciferase at $10^{-6} \mathrm{M}$ in CHO-K1 cells using the AR-EcoScreen assay. ${ }^{47)}$ BPF decreased luciferase induction by DHT in mouse NIH3T3 cells ${ }^{30}$ as well as human MDA0MB453 cells. $^{45)}$

\section{Estrogenic activities of BPS}

Estrogenic activity of BPS is rather controversial. It was first reported that BPS had no estrogenic activity using the yeast two-hybrid system. ${ }^{33)}$ Several authors, however, reported that BPS possessed estrogenic activity in MCF-7 cell ${ }^{40,43)}$ as well as weak estrogenic transcriptional activities in human MELN cells derived from MCF-7 cells. ${ }^{36)}$ Since the basic structural features which have been linked to ER binding, ${ }^{48}$ in particular the presence of a para hydroxyl group on each of the phenol rings, are shared by both BPA and BPS, BPS also may have modulatory effects toward ER binding potency. ${ }^{18,34,35,36 \text { ) }}$ BPS is also reported to have anti-androgenic activity in mouse NIH3T3 cells. ${ }^{34}$

B. Estrogenic activities of Tritan copolyesters

Three monomers of Tritan exhibited no evidence of interaction with either the AR or the alpha or beta ER receptors. ${ }^{9)}$ Similarly, the AR and ER transactivation assays, conducted with human cells and yeast reporters were negative as well. The lack of an estrogenic effect in in vitro assays was in good agreement with the in vivo uterotrophic assay in which none of the monomers demonstrated biological activities consistent with agonism of natural estrogens when administrated orally to ovariectomized female rats using a very wide range of dose levels. Similarly, the in vivo Hershberger assay shows no evidence of androgenic or antiandrogenic effects.

These results, however, are contrary to those reported by Yang et al. ${ }^{49)}$ They reported estrogenic effects of CHDM and DMT using the MCF-7 cell. Although details of the test results are not given, the authors report both compounds to be "estrogenic active". Authorities in the US and Europe have reviewed Tritan copolyesters for safety for food contact use, ${ }^{50,51)}$ however, further study of polymer as well as monomer on endocrine disruption appear to be warranted.

\section{Conclusion}

According to the investigations that employed several estrogenicity and androgenic assays, most BPs used as alternatives of BPA appear to have estrogenic and anti-androgenic activity as a common property. The modification of phenolic rings and bridging carbon, or the longer length of the alkyl substituents seems to influence the estrogen and anti-androgen activity, although the apparent relationship between their structure and estrogenic activity was not clarified. ${ }^{33)}$ For components of Tritan, no evidence of estrogen- or androgen-related effects was reported in one study, but a report suggesting otherwise is available. More studies with thorough study design, e.g., with long-term exposure period are warranted.

If current trends continue, production and subsequent environmental release of BPA alternatives are expected to increase. As some BPA substitutes such as BPF and BPS could be more persistent in environments compared to $\mathrm{BPA},{ }^{52}$ toxicological consequences in ecosystem should receive more attention. Further toxicological information of BPA alternatives is required to understand the environmental health implications of these alternatives and to develop proper management plans.

\section{References}

1. Diamanti-Kandarakis E, Bourguignon JP, Giudice LC, Hauser R, Prins GS, Soto AM, et al. Endocrine-disrupting chemicals: an Endocrine society 
scientific statement. Endocrine Reviews. 2009; 30: 293-342.

2. Liao C, Liu F, Alomirah H, Loi VD, Mohd MA, Moon $\mathrm{HB}$, et al. Bisphenol $\mathrm{S}$ in urine from the United States and seven Asian countries: occurrence and human exposures. Environ Sci Technol. 2012b; 46: 6860-6866.

3. Goodman JE, Witorsch RJ, McConnell EE, Sipes IG, Slayton TM, Yu CJ, et al. Weight-of-evidence evaluation of reproductive and developmental effects of low doses of bisphenol A. Crit Rev Toxicol. 2009; 39: 1-75.

4. Zhang X, Chang H, Wiseman S, He Y, Higley E, Jones $\mathrm{P}$, et al. Bisphenol A disrupts steroidogenesis in human H295R cells. Toxicol Sci. 2011; 121: 320-327.

5. Vandenberg LN, Chahoud I, Heindel JJ, Padmanabhan V, Paumgartten FJR, Schoenfelder G. Urinary, circulating, and tissue biomonitoring studies indicate widespread exposure to bisphenol A. Environ Health Perspect. 2010; 118: 1055-1070.

6. Volkel W, Colnot T, Csanady GA, Filsner JG, Dekant W. Metabolism and kinetics of bisphenol $\mathrm{A}$ in humans at low doses following oral administration. Chem Res Toxicol 2002; 15: 1281-1287.

7. Volkel W, Bittner N, Dekant W. Quantitation of bisphenol A and bisphenol A glucuronide in biological samples by high performance liquid chromatography-tandem mass spectrometry. Drug Metab Dispos 2005; 33: 1748-1757.

8. European Commission. 2011. Commission directive 2011/8/EU of 28 January 2011 on the restriction of use of Bisphenol A in plastic infant feeding bottles. Available: http://eur-lex.europa.eu/LexUriServ/ LexUriServ.do?uri=OJ:L:2011:026:0011:0014:EN:PDF [accessed 4 February 2013].

9. Osimitz TG, Eldridge ML, Sloter E, Welsh W, Ai N, Sayler GS, et al. Lack of androgenicity and estrogenicity of the three monomers used in Eastman's Tritan ${ }^{\mathrm{TM}}$ copolyesters. Food Chem Toxicol. 2012; 50: 2196-2205.

10. Danzl E, Sei K, Soda S, Ike M, Fujita M. Biodegradation of bisphenol $\mathrm{A}$, bisphenol $\mathrm{F}$ and bisphenol S in seawater. Int J Environ Res Public Health. 2009; 6: 1472-1484.

11. Akahori Y, Nakai M, Yamasaki K, Takatsuki M, Shimohigashi Y, Ohtaki M. Relationship between the results of in vitro receptor binding assay to human estrogen receptor alpha and in vivo uterotrophic assay: comparative study with 65 selected chemicals. Toxicol In Vitro. 2008; 22: 225-231.

12. Li Y, Burns KA, Arao Y, Luh CJ, Korach KS. Dif- ferential estrogenic actions of endocrine-disrupting chemicals bisphenol $\mathrm{A}$, bisphenol $\mathrm{AF}$, and zearalenone through estrogen receptor $\alpha$ and $\beta$ in vitro. Environ Health Perspect. 2012; 120: 10291035.

13. Matsushima A, Liu X, Okada H, Shimohigashi M, Shimohigashi $\mathrm{Y}$. Bisphenol AF is a full agonist for the estrogen receptor ER $\alpha$ but a highly specific antagonist for ERâ. Environ Health Perspect. 2010; 118: 1267-1272.

14. Perez P, Pulgar R, Olea-Serrano F, Villalobos M, Rivas A, Metzler M, et al. The estrogenicity of bisphenol A-related diphenylalkanes with various substituents at the central carbon and the hydroxyl groups. Environ Health Perspect. 1998; 106: 167174.

15. Stout MD. 2008. NTP research concept: Bisphenol AF. Available: http://ntp.niehs.nih.gov/files/ BPAF_Concept_final-100608_508.pdf [accessed 4 February 2013].

16. Yoshihara S, Mizutare T, Makishima M, Suzuki N, Fujimoto N, Igarashi K, et al. Potent estrogenic metabolites of bisphenol $\mathrm{A}$ and bisphenol $\mathrm{B}$ formed by rat liver S9 fraction: their structures and estrogenic potency. Toxicol Sci. 2004; 78: 50-59.

17. Fromme H, Küchler T, Otto T, Pilz K, Müller J, Wenzel A. Occurrence of phthalates and bisphenol $\mathrm{A}$ and $\mathrm{F}$ in the environment. Water Res. 2002; 36: $1429-1438$.

18. Kuruto-Niwa R, Nozawa R, Miyakoshi T, Shiozawa T, Terao Y. Estrogenic activity of alkylphenols, bisphenol $\mathrm{S}$, and their chlorinated derivatives using a GFP expression system. Environ Toxicol Pharmacol. 2005; 19: 121-130.

19. Simoneau C, Valzacchi S, Morkunas V, Van den Eede L. Comparison of migration from polyethersulphone and polycarbonate baby bottles. Food Addit Contam Part A Chem Anal Control Expo Risk Assess. 2011; 28: 1763-1768.

20. Watanabe M, Fukazawa H, Shiraishi F, Shiraishi H, Shiozawa T, Terao T. Analysis and estrogenic activity of bisphenol A and other chemicals released from waste paper by pulping. J Environ Chem. 2004; 14: 65.

21. Ball GL, McLellan CJ, Bhat VS. Toxicological review and oral risk assessment of terephthalic acid (TPA) and its esters: a category approach. Crit Rev Toxicol. 2012; 42: 28-67.

22. US EPA. 2010. Office of Pollution Prevention and Toxics. ChemRTK 1990 HPV challenge program chemicals list. Available: http://www.epa.gov/hpv/ pubs/update/hpv_1990.pdf [accessed 4 February 2013]. 
23. OECD. 2009. The 2007 OECD list of high production volume chemicals. ENV/JM/MONO(2009)40. OECD. Paris, France 23 October 2009. Available: http://search.oecd.org/officialdocuments/displaydocumentpdf/?cote $=$ env/jm/mono(2009)40\&doclanguage $=$ en [accessed 4 February 2013].

24. Liao C, Liu F, Guo Y, Moon HB, Nakata H, Wu $\mathrm{Q}$, et al. Occurrence of eight bisphenol analogues in indoor dust from the United States and several Asian countries: Implications for human exposure. Environ Sci Technol. 2012d; 46: 9138-9145.

25. Cobellis L, Colacurci N, Trabucco E, Carpentiero C, Grumetto L. Measurement of bisphenol A and bisphenol B levels in human blood sera from healthy and endometriotic women. Biomed Chromatogr. 2009; 23: 1186-1190.

26. Cunha SC, Fernandes JO. Quantification of free and total bisphenol $\mathrm{A}$ and bisphenol $\mathrm{B}$ in human urine by dispersive liquid-liquid microextraction (DLLME) and heart-cutting multidimensional gas chromatography-mass spectrometry (MD-GC/MS). Talanta. 2010; 83: 117-125.

27. Grumetto L, Montesano D, Seccia S, Albrizio S, Barbato F. Determination of bisphenol A and bisphenol $\mathrm{B}$ residues in canned peeled tomatoes by reversed-phase liquid chromatography. J Agric Food Chem. 2008; 56: 10633-10637.

28. Gallart-Ayala H, Moyano E, Galceran M.T. Analysis of bisphenols in soft drinks by on-line solid phase extraction fast liquid chromatography-tandem mass spectrometry. Anal Chim Acta. 2011; 683: $227-233$.

29. Liao C, Kannan K. Widespread occurrence of bisphenol A in paper and paper products: Implications for human exposure. Environ Sci Technol. 2011; 45: 9372-9379.

30. Liao C, Liu F, Kannan K. Bisphenol S, a new bisphenol analogue, in paper products and currency and its association with bisphenol a residues. Environ Sci Technol. 2012a; 46: 6515-6522.

31. Liao C, Liu F, Moon HB, Yamashita N, Yun S, Kannan K. Bisphenol analogues in sediments from industrialized areas in the United States, Japan, and Korea: spatial and temporal distributions. Environ Sci Technol. 2012c; 46: 11558-11565.

32. Viñas P, Campillo N, Martínez-Castillo N, Hernández-Córdoba M. Comparison of two derivatizationbased methods for solid-phase microextraction-gas chromatography-mass spectrometric determination of bisphenol A, bisphenol $\mathrm{S}$ and bisphenol migrated from food cans. Anal Bioanal Chem. 2010; 397: 115-125.

33. Chen MY, Ike M, Fujita M. Acute toxicity,

http://www.kseh.org/ mutagenicity, and estrogenicity of bisphenol-A and other bisphenols. Environ Toxicol. 2002; 17: 8086.

34. Kitamura S, Suzuki T, Sanoh S, Kohta R, Jinno N, Sugihara K, et al. Comparative study of the endocrine-disrupting activity of bisphenol A and 19 related compounds. Toxicol Sci. 2005; 84: 249259.

35. Blair RM, Fang H, Branham WS, Hass BS, Dial SL, Moland CL, Tong W, Shi L, Perkins R, Sheehan D.M. The estrogen receptor relative binding affinities of 188 natural and xenochemicals: structural diversity of ligands. Toxicol Sci. 2000; 54: 138-153.

36. Grignard E, Lapenna S, Bremer S. Weak estrognic transcriptional activities of bisphenol $\mathrm{A}$ and bisphenol S. Toxicol In Vitro. 2012; 26: 727-731.

37. Bermudez DS, Gray Jr LE, Wilson VS. Modeling the interaction of binary and ternary mixtures of estradiol with bisphenol A and bisphenol AF in an in vitro estrogen-mediated transcriptional activation assay (T47D-KBluc). Toxicol Sci. 2010; 116: 477-487.

38. Yamasaki K, Takeyoshi M, Sawaki M, Imatanaka $\mathrm{N}$, Shinoda K, Takatsuki M. Immature rat uterotrophic assay of 18 chemicals and Hershberger assay of 30 chemicals. Toxicology. 2003; 183: 93-115.

39. Feng Y, Yin J, Jiao Z, Shi J, Li M, Shao B. Bisphenol AF may cause testosterone reduction by directly affecting testis function in adult male rats. Toxicol Lett. 2012; 211: 201-209.

40. Hashimoto Y, Moriguchi Y, Oshima H, Kawaguchi M, Miyazaki K, Nakamura M. Measurement of estrogenic activity of chemicals for the development of new dental polymers. Toxicol In Vitro. 2001; 15: 421.

41. Rivas A, Lacroix M, Olea-Serrano F, Laïos I, Leclercq G, Olea N. Estrogenic effect of a series of bisphenol analogues on gene and protein expression in MCF-7 breast cancer cells. J Steroid Biochem Mol Biol. 2002; 82: 45-53.

42. Yamasaki K, Takeyoshi M, Yakabe Y, Sawaki M, Imatanaka N, Takatsuki M. Comparison of reporter gene assay and immature rat uterotrophic assay of twenty-three chemicals. Toxicology. 2002; 170: 21-30.

43. Hashimoto Y, Nakamura M. Estrogenic activity of dental materials and bisphenol-A related chemicals in vitro. Dent Mater J. 2000; 19: 245.

44. Zhang HC, Chen LY, Liu SS, Yin DQ. Jointed estrogenic activities of bisphenol A and three of its analogs. Huan Jing Ke Xue. 2009; 30: 260-265. 
45. Stroheker T, Picard K, Lhuguenot JC, CanivencLavier MC, Chagnon MC. Steroid activities comparison of natural and food wrap compounds in human breast cancer cell lines. Food Chem Toxicol. 2004; 42: 887-897.

46. Cabaton N, Dumont C, Severin I, Perdu E, Zalko D, Cherkaoui-Malki M, et al. Genotoxic and endocrine activities of bis(hydroxyphenyl)methane (bisphenol F) and its derivatives in the HepG2 cell line. Toxicology 2009; 255: 15-24.

47. Satoh K, Ohyama K, Aoki N, Iida M, Nagai F. Study on anti-androgenic effects of bisphenol A diglycidyl ether (BADGE), bisphenol F diglycidyl ether (BFDGE) and their derivatives using stably transfected with human androgen receptor, AREcoScreen. Food Chem Toxicol. 2004; 42: 983993.

48. Gallegos Saliner A, Amat L, Carbo-Dorca R, Schultz TW, Cronin MT. Molecular quantum similarity analysis of estrogenic activity. J Chem Inf Comput Sci. 2003; 43: 1166-1176.
49. Yang C, Yaniger S, Jordan VC, Klein D, Bittner G. Most plastic products release estrogenic chemicals: a potential health problem that can be solved. Environ Health Perspect. 2011; 119: 989-996.

50. US FDA. 2011. Inventory of Effective Food Contact Substance (FCS) Notifications: FCN No. 1041. Available: http://www.accessdata.fda.gov/ scripts/fcn/fcnDetailNavigation.cfm?rpt=fcsListing \&id=1041 [accessed 4 February 2013].

51. European Commission. 2011. Commission Regulation (EU) No. 10/2011 of 14 January 2011 on Plastic Materials and Articles Intended to Come into Contact with Food Text with EEA Relevance. Available: http://eurlex.europa.eu/LexUriServ/LexUriServ.do?uri=OJ:L:2011:012:0001:01:EN:HTML [accessed 4 February 2013].

52. Ike M, Chen MY, Danzl E, Sei K, Fujita M. Biodegradation of a variety of bisphenols under aerobic and anaerobic conditions. Water Sci Technol. 2006; 53: 153-159. 